The Egyptian Journal of Hospital Medicine (January 2021) Vol. 82 (1), Page 43-47

\title{
Reticulocyte Haemoglobin Content and Soluble Transferrin Receptor Concentration as Markers of Iron Stores in Chronic Kidney Disease in Egyptian Patients Hassan Abd- Elhady Ahmed ${ }^{1}$, Yassein Salah Yassein ${ }^{1}$, Ahmed Ragheb Tawfeek ${ }^{1}$, Amira M. Fouad Shehata ${ }^{2}$, Karim Salah Mahmoud* \\ Departments of ${ }^{1}$ Internal Medicine and ${ }^{2}$ Clinical Pathology, Faculty of Medicine, Menoufia University \\ * Corresponding author: Karim Salah Mahmoud, Mobile: +20 01098798540, E-mail: kareem_salah2000@ yahoo.com
}

\begin{abstract}
Background: Chronic kidney disease (CKD), also known as chronic renal disease, is progressive loss in kidney function over a period of months or years. It is an internationally recognized public health problem affecting $5-10 \%$ of the world population.

Objective: To evaluate the role of reticulocyte hemoglobin content and soluble transferrin receptor concentration for detection of iron deficiency anemia in chronic kidney disease in Egyptian patients compared to conventional markers.

Patients and Methods: This is a cross-sectional study that had been done on 177 Chronic Kidney Disease Egyptian patients with iron deficiency anemia. Patients had been selected from the Outpatient Clinics and Hemodialysis Unit of the Internal Medicine Department, Menoufia University Hospital. Subjects had been divided into three groups: group 1 (Hemodialysis group): A number of 49 chronic hemodialysis patients (more than 3 months), group 2 (CKD group): A number of 88 patients with chronic kidney disease stages 3-5 and group 3 (Controls): Included 40 healthy subjects as a control group and had been matched with other groups regarding age and gender.

Results: There was statistically significant difference between the studied groups regarding serum iron, serum transferrin and serum ferritin. There was statistically significant difference between group I, II compared to control regarding total iron binding capacity (TIBC), Hb, reticulocyte hemoglobin content and serum soluble transferrin receptors (sTfR).

Conclusion: This study concluded that sTfR, and TfR-F index proved to be important tools to determine iron deficiency anaemia (IDA) in RH anemic patients and TFR index has superior accuracy than sTfR.
\end{abstract}

Keywords: Chronic Kidney Disease, Reticulocyte Hemoglobin content, soluble transferrin receptor concentration.

\section{INTRODUCTION}

Chronic kidney disease (CKD), also known as chronic renal disease, is progressive loss in kidney function over a period of months or years. It is an internationally recognized public health problem affecting $5-10 \%$ of the world population ${ }^{(1)}$.

Anemia as a frequent complication in chronic kidney disease (CKD). It is often accompanied by various clinical symptoms, such as impaired physical capacity, decreased neurocognitive function, and poor quality of life (2). Causes of anemia in CKD include decreased production of erythropoietin, iron deficiency, inflammation, and the accumulation of uremic toxins ${ }^{(3)}$.

A common clinical problem is distinguishing between functional iron deficiency and inflammatory iron block, since the TSAT could be above the $20 \%$ and circulating ferritin could be 100 to $700 \mathrm{ng} / \mathrm{mL}$ in both clinical situations. During functional iron deficiency, ESA treatment induces a decrease in circulating ferritin levels, which however remain elevated (generally more than $100 \mathrm{ng} / \mathrm{mL}$ ). In contrast, inflammatory process is characterized by an abrupt increase of serum ferritin levels that is associated with a sudden drop in the transferrin saturation (TSAT). Measurement of high sensitivity C-reactive protein (CRP) may be indicated if occult inflammation is a concern. In this situation, no further intravenous (IV) iron should be administrated until the inflammatory condition has been resolved ${ }^{(4)}$.

The hemoglobin content of reticulocyte and soluble transferrin receptor concentration are now considered to be the most useful for diagnostic purposes. Moreover, the concentration of soluble transferrin receptor confirmed its high diagnostic value in the detection of iron deficiencybased anemia in patients undergoing dialysis for chronic renal failure at the end-stage compared to conventional serum iron markers ${ }^{(5)}$.

We aimed in this study to evaluate the role of reticulocyte hemoglobin content and soluble transferrin receptor concentration for detection of iron deficiency anemia in chronic kidney disease in Egyptian patients, compared to conventional markers (serum ferritin and transferrin saturation).

\section{PATIENTS AND METHODS}

This is a cross-sectional study that had been done on a suitable number of chronic kidney disease Egyptian patients with iron deficiency anemia. Patients had been selected from the Outpatient Clinics and Hemodialysis Unit of the Internal Medicine Department, Menoufia University Hospital, Egypt during the period between $2017-2020$.

This article is an open access article distributed under the terms and conditions of the Creative Commons Attribution (CC BY-SA) license (http://creativecommons.org/licenses/by/4.0/) 
Ethical and patients' approval: This study was approved by the University Hospital Medical Committee of Menoufia university and carried out according to the principles of the declaration of Helsinki. Informed consents had been obtained from all subjects participating in the study.

A sample size of 177 subjects who had been divided into three groups:

- Group 1 (Hemodialysis group): A number of 49 chronic hemodialysis patients (more than 3 months).

- Group 2 (CKD group): A number of 88 patients with chronic kidney disease stages 3-5. (N.B: CKD patients who are under conservative therapy and prepared for renal replacement therapy had been also included).

- Group 3 (Controls): Included 40 healthy subjects as control group and had been matched with other groups as regards age and gender.

\section{Inclusion criteria:}

Adult patients ( $\geq 18$ years old) with CKD stages 3 to 5 with or without hemodialysis who suffer from iron deficiency anemia. Iron deficiency anemia is diagnosed by one or more of the following:

- Hemoglobin less than $10 \mathrm{mg} / \mathrm{dl}$.

- Hematocrit value less than $30 \%$.

- Serum ferritin less than $100 \mathrm{ng} / \mathrm{dl}$.

- Transferrin saturation less than $20 \%$.

\section{Exclusion criteria:}

- Patients with other types of anemia or haemoglobinopathies.

- Malignancies.

- Pregnant females.

- Patients with significant bleeding (e.g. GIT bleeding).

- Patients with evidence of inflammation or infectious disease.

- Patients with MCV > $80 \mathrm{fl}$.

Clinical evaluation comprising full medical history laying stress on manifestations of anemia, frequency of bleeding and frequency of blood transfusion. Laboratory analysis included complete blood counts, renal and electrolytes profiles, serum iron, serum ferritin, (TIBC), the serum soluble transferrin receptors (sTfR), and reticulocyte $\mathrm{Hb}$ content.

\section{Statistical analysis}

Collected data throughout history, basic clinical examination, laboratory investigations and outcome measures were coded, entered and analyzed using Microsoft Excel software. The collected data were tabulated and analyzed by SPSS (statistical package for social science) version 25 (IBM, Armonk, NY, USA) on IBM compatible computer. According to the type of data, qualitative data were represented as number and percentage, quantitative continues group data were represented by mean \pm SD. Comparison of clinical characteristics of the groups was done using ANOVA test. P-value of $\leq 0.05$ was considered statistically significant $\&<0.001$ for high significant result.

\section{RESULTS}

Our study included 117 subjects, their age ranged 24-65 years. There was statistically significant difference between group I and II as regards duration of illness and BMI ( $\mathrm{p}=0.031$ and 0.002 respectively). In addition, there was statistically significant difference between groups I and III as regards BMI $(\mathrm{p}=0.014)$ (Table 1$)$.

Serum creatinine and BUN were higher in group I. There was statistically significant difference between the studied groups regarding serum creatinine. In addition, there was statistically significant difference between groups I \& II compared to control regarding serum BUN and eGFR ( $p<0.001)$ (table 2). The majority of patients in groups I and II (65.3\% and $63.6 \%$ respectively) had moderate anemia with statistically significant difference between groups I \& II compared to control regarding severity of anemia (table 3).

There was statistically significant difference between the studied groups regarding serum iron, transferrin and serum ferritin. There was statistically significant difference between groups I and II compared to control regarding TIBC, $\mathrm{Hb}$, reticulocyte hemoglobin content and sTfR (table 4).

Table (1): Comparison of the clinical data between the three studied groups

\begin{tabular}{|c|c|c|c|c|c|}
\hline & & $\begin{array}{c}\text { Group I } \\
n=49\end{array}$ & $\begin{array}{c}\text { Group II } \\
n=88\end{array}$ & $\begin{array}{c}\text { Group III } \\
n=40\end{array}$ & $P$ value \\
\hline Age (years) & $\begin{array}{c}\text { Range } \\
\text { Mean } \pm \text { SD }\end{array}$ & $\begin{array}{c}32-65 \\
53.33 \pm 3.79\end{array}$ & $\begin{array}{c}24-59 \\
52.16 \pm 1.79\end{array}$ & $\begin{array}{c}28-61 \\
50.62 \pm 2.8\end{array}$ & $\begin{array}{l}\mathrm{P} 1=0.261 \\
\mathrm{P} 2=0.472 \\
\mathrm{P} 3=0.153\end{array}$ \\
\hline $\begin{array}{l}\text { Duration of } \\
\text { illness (years) }\end{array}$ & $\begin{array}{c}\text { Range } \\
\text { Mean } \pm \text { SD }\end{array}$ & $\begin{array}{c}5-9 \\
6.34 \pm 1.7\end{array}$ & $\begin{array}{c}2-7 \\
4.01 \pm 1.66 \\
\end{array}$ & - & $\mathrm{P} 1=\mathbf{0 . 0 3 1} *$ \\
\hline BMI kg/m²) & $\begin{array}{c}\text { Range Mean } \\
\pm \mathrm{SD}\end{array}$ & $\begin{array}{c}22.2-31 \\
27.15 \pm 2.11\end{array}$ & $\begin{array}{c}24.2-32.3 \\
32.91 \pm \\
1.47\end{array}$ & $\begin{array}{c}26-34 \\
30.85 \pm 4.76\end{array}$ & $\begin{aligned} \mathrm{P} 1 & =\mathbf{0 . 0 0 2} \\
\mathrm{P} 2 & =\mathbf{0 . 0 1 4}\end{aligned}$ \\
\hline
\end{tabular}

P1 = Group I compared to group II; P2= Group I compared to group III; P3= Group II compared to group III;

$* \mathrm{P}$ value $<0.05$ is considered significant; $\quad * * \mathrm{P}$ value $<0.001$ is considered highly significant 
https://ejhm.journals.ekb.eg/

Table (2): Comparative study of the renal function indices among the three studied groups

\begin{tabular}{|c|c|c|c|c|c|}
\hline & & Group (I), n=49 & Group II, $\mathbf{n = 8 8}$ & Group III, n=40 & P value \\
\hline $\begin{array}{l}\text { S. creatinine } \\
\text { (mg/dl) }\end{array}$ & Mean \pm SD & $8.3 \pm 2.04$ & $5.2 \pm 1.95$ & $0.9 \pm 0.19$ & $\begin{array}{l}\mathrm{P} 1=\mathbf{0 . 0 4 2} * \\
\mathrm{P} 2<\mathbf{0 . 0 0 1} * * \\
\mathrm{P} 3=\mathbf{0 . 0 0 1} *\end{array}$ \\
\hline $\begin{array}{l}\text { Serum BUN } \\
(\mathbf{m g} / \mathbf{d l})\end{array}$ & Mean \pm SD & $117.3 \pm 6.13$ & $114.9 \pm 8.62$ & $30.4 \pm 0.77$ & $\begin{array}{l}\mathrm{P} 1=0.152 \\
\mathrm{P} 2<\mathbf{0 . 0 0 1} * * \\
\mathrm{P} 3<\mathbf{0 . 0 0 1} * *\end{array}$ \\
\hline $\begin{array}{l}\text { eGFR } \\
\mathrm{ml} / \mathrm{min}\end{array}$ & Mean \pm SD & $28.6 \pm 5.83$ & $23.7 \pm 5.25$ & $113.7 \pm 7.31$ & $\begin{array}{l}\mathrm{P} 1=0.063 \\
\mathrm{P} 2<\mathbf{0 . 0 0 1} * * \\
\mathrm{P} 3<\mathbf{0 . 0 0 1} * *\end{array}$ \\
\hline
\end{tabular}

P1 = Group I compared to group II; P2= Group I compared to group III; P3= Group II compared to group III; $\quad * \mathrm{P}$ value $<0.05$ is considered significant; $\quad * * \mathrm{P}$ value $<0.001$ is considered highly significant.

Table (3): Severity of anemia in chronic kidney disease patients

\begin{tabular}{|c|c|c|c|c|}
\hline . & Group (I), n=49 & Group II, n=88 & Group III, $n=40$ & $P$ value \\
\hline Mild No (\%) & $12(24.5)$ & $24(27.3)$ & $32(80)$ & $\begin{array}{l}\mathrm{P} 1=0.281 \\
\mathrm{P} 2=\mathbf{0 . 0 4 2} * \\
\mathrm{P} 3=\mathbf{0 . 0 3 1} *\end{array}$ \\
\hline Moderate No (\%) & $32(65.3)$ & $56(63.6)$ & 7 (17.5) & $\begin{array}{l}\mathrm{P} 1=0.164 \\
\mathrm{P} 2<\mathbf{0 . 0 0 1} * * \\
\mathrm{P} 3<\mathbf{0 . 0 0 1} *\end{array}$ \\
\hline Sever No (\%) & $5(10.2)$ & $8(9.1)$ & $1(2.5)$ & $\begin{array}{l}\text { P1 }=0.148 \\
\text { P2 }=\mathbf{0 . 0 1 4} * \\
\text { P3 }=\mathbf{0 . 0 2 7} *\end{array}$ \\
\hline
\end{tabular}

P1 = Group I compared to group II; P2= Group I compared to group III; P3= Group II compared to group III;

$* \mathrm{P}$ value $<0.05$ is considered significant; $\quad * * \mathrm{P}$ value $<0.001$ is considered highly significant

Table (4): Comparison of the hematological data of the studied groups

\begin{tabular}{|c|c|c|c|c|c|}
\hline & & Group (I), n=49 & Group II, $\mathbf{n = 8 8}$ & Group III, $\mathrm{n}=40$ & P value \\
\hline S. Iron $(\mu \mathrm{g} / \mathrm{dL})$ & $\begin{array}{l}\text { Mean } \pm \\
\text { SD }\end{array}$ & $84.6 \pm 5.24$ & $65.2 \pm 4.91$ & $68.5 \pm 4.16$ & 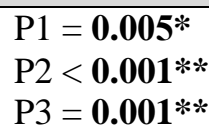 \\
\hline TIBC $(\mu \mathrm{g} / \mathrm{dL})$ & $\begin{array}{l}\text { Mean } \pm \\
\text { SD }\end{array}$ & $223.3 \pm 15.16$ & $236.8 \pm 17.62$ & $244.4 \pm 19.74$ & $\begin{array}{l}\mathrm{P} 1=0.073 \\
\mathrm{P} 2=\mathbf{0 . 0 0 2} * \\
\mathrm{P} 3=\mathbf{0 . 0 0 4} *\end{array}$ \\
\hline TSAT \% & $\begin{array}{l}\text { Mean } \pm \\
\text { SD }\end{array}$ & $29.7 \pm 3.83$ & $30.3 \pm 4.25$ & $33.1 \pm 5.61$ & $\begin{array}{l}\mathrm{P} 1=0.281 \\
\mathrm{P} 2=0.162 \\
\mathrm{P} 3=0.072\end{array}$ \\
\hline $\begin{array}{l}\text { S. Ferritin } \\
(\mathbf{n g} / \mathbf{m L})\end{array}$ & $\begin{array}{l}\text { Mean } \pm \\
\text { SD }\end{array}$ & $674.5 \pm 35.3$ & $217.2 \pm 24.8$ & $128.1 \pm 19.3$ & $\begin{array}{l}\mathrm{P} 1<\mathbf{0 . 0 0 1} \text { *** } \\
\mathrm{P} 2<\mathbf{0 . 0 0 1} \text { *** } \\
\mathrm{P} 3<\mathbf{0 . 0 0 1} \text { *** }\end{array}$ \\
\hline $\begin{array}{l}\text { Transferrin } \\
\text { (mg/dL) }\end{array}$ & $\begin{array}{l}\text { Mean } \pm \\
\text { SD }\end{array}$ & $186.5 \pm 9.3$ & $229.4 \pm 23.2$ & $257.7 \pm 25.6$ & $\begin{array}{l}\mathrm{P} 1<\mathbf{0 . 0 0 1} * * \\
\mathrm{P} 2<\mathbf{0 . 0 0 1} * * \\
\mathrm{P} 3=\mathbf{0 . 0 1 3}\end{array}$ \\
\hline $\begin{array}{l}\text { Hemoglobin } \\
\text { (g/dL) }\end{array}$ & $\begin{array}{l}\text { Mean } \pm \\
\text { SD }\end{array}$ & $8.6 \pm 1.4$ & $8.9 \pm 1.8$ & $14.2 \pm 3.5$ & $\begin{array}{l}\mathrm{P} 1=0.834 \\
\mathrm{P} 2=\mathbf{0 . 0 4 2} * \\
\mathrm{P} 3=\mathbf{0 . 0 4 7} *\end{array}$ \\
\hline $\begin{array}{l}\text { Reticulocyte } \\
\text { Hemoglobin } \\
\text { content }(\mathrm{CHr})(\mathrm{pg})\end{array}$ & $\begin{array}{l}\text { Mean } \pm \\
\text { SD }\end{array}$ & $29.1 \pm 2.3$ & $29.8 \pm 3.6$ & $32.6 \pm 1.3$ & $\begin{array}{l}\mathrm{P} 1=0.564 \\
\mathrm{P} 2=\mathbf{0 . 0 2 5}^{*} \\
\mathrm{P} 3=\mathbf{0 . 0 3 9}^{*}\end{array}$ \\
\hline sTfR (mg/l) & $\begin{array}{l}\text { Mean } \pm \\
\text { SD }\end{array}$ & $1.06 \pm 0.3$ & $1.51 \pm 0.30$ & $1.82 \pm 0.07$ & $\begin{array}{l}\mathrm{P} 1=0.261 \\
\mathrm{P} 2=\mathbf{0 . 0 2 7} * \\
\mathrm{P} 3=\mathbf{0 . 0 4 6}^{*}\end{array}$ \\
\hline
\end{tabular}

sTfR; soluble transferrin receptor $\quad$ P1 = Group I compared to group II; P2= Group I compared to group III;

P3= Group II compared to group III; $\quad *$ P value $<0.05$ is considered significant $* * \mathrm{P}$ value $<0.001$ is considered highly significant 


\section{DISCUSSION}

Chronic kidney disease (CKD) is typically associated with normochromic, normocytic anemia that manifests as a reduced reticulocyte response and bone marrow erythroid hyperplasia. The anemia associated with CKD has many consequences for patients; including reduced quality of life, increased cardiovascular disease and increased mortality ${ }^{(\mathbf{6})}$.

There was statistically significant difference between the studied groups regarding duration of illness and BMI. Their age ranged 24-65 years. Our results are supported by study of Alzahrani et al. ${ }^{(7)}$ as they reported that the mean value of body mass index (BMI) showed a very high significant reduction in groups I and II when compared to the control group $(\mathrm{p}<0.001)$. Moreover, on comparing group II to group I, a significant reduction was noticed ( $p<0.05)$. Group I; included 15 cases with anemia of CKD and their glomerular filtration rate (GFR) was 15.5 - 29.6 $\mathrm{ml} / \mathrm{min} / 1.73 \mathrm{~m}^{2}$ (stages; III \& IV CKD) and they were managed conservatively. Group II included 10 anemic cases with end stage renal disease (Stage V CKD, GFR was $6.1-13.7 \mathrm{ml} / \mathrm{min} / 1.73 \mathrm{~m} 2$ ) and they were under regular hemodialysis. Another 10 healthy participants with matched age and gender served as control group (group III).

The present study showed that there was statistically significant difference between the studied groups regarding serum creatinine. There was statistically significant difference between groups I and II compared to control regarding serum BUN and eGFR. In the study of Gupta $\boldsymbol{e t}$ al. ${ }^{(8)}$, the mean of serum creatinine of their participants was 5.39. The mean of BUN was 117.52 and the mean of GFR was 21.04.

The current study showed that more than half of them had diabetes mellitus and $20 \%$ of them had hypertension. Our results were supported by study of Gupta et al. ${ }^{\left({ }^{(9)}\right.}$ as they demonstrated that $49 \%$ of their participants had DM and 9\% of them had hypertension. In the study of Yin et al. ${ }^{(10)}, 20 \%$ of their studied group were diabetics and $12.5 \%$ of them had hypertension. Furthermore, Venkatesan et al. (11) revealed that diabetic nephropathy, hypertension and chronic glomerulonephritis found to contribute by $54.4 \%$ (37), $27.9 \%$ (19) and $13.2 \%$ (9) cases respectively. Two patients had lupus nephritis $(2.9 \%)$. One patient had autosomal dominant polycystic kidney disease (1.5\%).

In the study in our hands, there was statistically significant difference between groups I and II compared to control regarding severity of anemia. Our results are supported by study of Venkatesan $\boldsymbol{e t}$ al. ${ }^{(11)}$ as they reported that there was statistically significant difference among the studied groups as regards level of $\mathrm{Hb}$ and severity of anemia.

In the study of Alzahrani et al. ${ }^{(7)}$ the red blood corpuscular indices (RBCs counts, $\mathrm{Hb}, \mathrm{HCT} \%$, and $\mathrm{MCH}$ ) all were significantly decreased in both groups I and II before treatment, as compared to the control group. On comparing group, I before and after treatment there was no significant change, whereas, on comparing group II after treatment to group II before treatment, a significant increase was noticed for RBCs count, $\mathrm{Hb}$ and MCV ( $\mathrm{p}$ < 0.05). Moreover, a high significant increase was evident for HCT\% $(p<0.001)$ and a very high significant increase for $\mathrm{MCH}(\mathrm{p}<0.0001)$ was detected showing the effect of treatment on these indices.

The present study showed that there was statistically significant difference between the studied groups regarding serum iron, transferrin and serum ferritin. There was statistically significant difference between groups I \& II compared to control regarding TIBC, Hb, Reticulocyte Hemoglobin content and sTfR. Our results are supported by study of Gupta et $\boldsymbol{a l}^{{ }^{\left({ }^{(9)}\right.} \text { as }}$ they revealed that the mean value of serum iron in study group was $101.5 \pm 9.2 \mu \mathrm{g} / \mathrm{dl}$ at baseline and in controls was $66.65 \pm 28.52 \mu \mathrm{g} / \mathrm{dl}$. This difference was statistically significant. The serum ferritin was much higher in study group $(513.82 \pm 505.07 \mathrm{ng} / \mathrm{ml})$ than in the control group $(88.66 \pm 132.92 \mathrm{ng} / \mathrm{ml})$. TIBC was lower $(297.2 \pm 100.1 \mu \mathrm{g} / \mathrm{dl})$ in CKD patients with a higher TSAT value $(32.2 \pm 15.2 \%)$ as compared to the control group. The difference was statistically significant. According to, Venkatesan et al. (11) they reported that in Group 1, mean serum ferritin was 11.34 $\pm 3.88 \mu \mathrm{g} / \mathrm{L}$ and sTfR $2.34 \pm 0.55 \mu \mathrm{g} / \mathrm{ml}$. In Group 2, the mean serum ferritin and mean sTfR were $28.70 \pm 26.59$ $\mu \mathrm{g} / \mathrm{L}$ and $1.82 \pm 0.68 \mu \mathrm{g} / \mathrm{ml}$, respectively. In Group 3, the mean serum ferritin was $281.81 \pm 142.39 \mu \mathrm{g} / \mathrm{L}$ and sTfR of $1.28 \pm 0.50 \mu \mathrm{g} / \mathrm{ml}$.

\section{CONCLUSION}

This study concluded that sTfR, and TfR-F index proved to be important tools to determine IDA in RH anaemic patients and TFR index has superior accuracy than sTfR. When sTfR and TfR-F index used in combination, their diagnostic value reaches the best. The present data support that $\mathrm{CHr}$ and sTfR are sensitive markers of iron status for the diagnosis of iron deficiency and the differential diagnosis of iron deficiency. Therefore, measurement of one or both of these parameters to confirm iron deficiency before the development of anemia or in situations where traditional markers of iron status are of little help, may significantly 
improve the diagnosis and management of iron deficiency.

\section{REFERENCES}

1. Martínez-Castelao A, Górriz J, Bover J (2014): Consensus document for the detection and management of chronic kidney disease. Nefrologia, 34 (2): 243-62.

2. Astor B, Muntner P, Levin A et al. (2002): Association of kidney function with anemia the Third National Health and Nutrition Examination Survey. Arch Intern Med., 162: 1401-1408.

3. Smith R (2010): The clinical and economic burden of anemia. Am J Manag Care, 16: 59-66.

4. Rivera R, Lullo L, Antonio D (2016): Anaemia in patients with chronic kidney disease current screening and management approaches. Nephrol Renal Dis ., 1 (1): 1-9.

5. Kurzawa T, Owczarek A, Strzelczyk J (2016): The Content of Reticulocyte Hemoglobin and Serum Concentration of the Soluble Transferrin Receptor for Diagnostics of Anemia in Chronically Hemodialyzed Patients. Adv Clin Exp Med., 3: 425-431.

6. KDOQI National Kidney Foundation (2006): KDOQI clinical practice guidelines and clinical practice recommendations for anemia in chronic kidney disease. Am J Kidney Dis., 47: S11-145.

7. Alzahrani A, Alzahrani A, Al Nashar N et al. (2013): Assessment of iron status in anemic children with chronic kidney disease. The Egyptian Journal of Hospital Medicine, 52 (1): 658-669.

8. Gupta D, Choudhary R, Sharma M et al. (2016): Role of soluble transferrin receptor and soluble transferrin receptor index in diagnosing iron deficiency anemia in patients with chronic kidney disease. Astrocyte, 3 (3): 125-28.

9. Gupta S, Uppal B, Pawar B (2009): Is soluble transferrin receptor a good marker of iron deficiency anemia in chronic kidney disease patients? Indian Journal of Nephrology, 19 (3): 96.

10. Yin P, Song Y, Li J (2017): Soluble transferrin receptor as a marker of erythropoiesis in patients undergoing highflux hemodialysis. Bosnian Journal of Basic Medical Sciences, 17 (4): 333.

11. Venkatesan M, Saxena S, Kumar A (2019): Evaluation of iron status in patients of chronic kidney disease-A study to assess the best indicators including serum transferrin receptor assay. Indian Journal of Nephrology, 29 (4): 24852. 